\title{
L-Proline-Catalyzed Synthesis of Phthalimide Derivatives and Evaluation of Their Antioxidant, Anti-Inflammatory, and Lipoxygenase Inhibition Activities
}

\author{
Shagufta Perveen (iD) and Raha Orfali \\ Department of Pharmacognosy, College of Pharmacy, King Saud University, P.O. Box 2457, Riyadh 11451, Saudi Arabia \\ Correspondence should be addressed to Shagufta Perveen; shagufta792000@yahoo.com
}

Received 3 January 2018; Revised 19 March 2018; Accepted 10 May 2018; Published 1 August 2018

Academic Editor: Radhey Srivastava

Copyright (c) 2018 Shagufta Perveen and Raha Orfali. This is an open access article distributed under the Creative Commons Attribution License, which permits unrestricted use, distribution, and reproduction in any medium, provided the original work is properly cited.

\begin{abstract}
A study was planned to synthesize the phthalimide derivatives as phthalimides have versatile biological activities. To synthesize the phthalimide derivatives, initially the reaction was optimized with various catalysts, and L-proline was found to be the best catalyst as it provided excellent yield. A series of phthalimide derivatives was synthesized by facile one-top reaction of phthalic acid with aryl amines under mild reaction conditions in the presence of L-proline as catalyst. Products were obtained in excellent yields and structurally characterized by ${ }^{1} \mathrm{H},{ }^{13} \mathrm{C} \mathrm{NMR}$, and mass spectral data. Products 1-7 were evaluated for antioxidant, antiinflammatory, and lipoxygenase enzyme inhibition activities. Compounds $\mathbf{1}$ and $\mathbf{4}$ showed potent antioxidant activity under $\mathrm{DPPH}$ with $\mathrm{IC}_{50}$ values 27.3 and $25.0 \mu \mathrm{M}$ when compared with the standard BHA $\left(\mathrm{IC}_{50}=44.2 \mu \mathrm{M}\right)$, respectively. Compounds 1 and 4 further showed strong lipoxygenase inhibition activity with $\mathrm{IC}_{50}$ values 21.34 and $20.45 \mu \mathrm{M}$ when compared with standard baicalein $\left(\mathrm{IC}_{50}=22.60 \mu \mathrm{M}\right)$, respectively. Compound 2 was found to be promising and about equal to the used standard aspirin in the inhibition of bovine serum albumin denaturation, while other compounds showed weak-to-moderate $\%$ inhibition.
\end{abstract}

\section{Introduction}

Heterocyclic compounds have been found to possess important physiological and pharmaceutical properties [1]. Phthalimides and their $\mathrm{N}$-substituted derivatives belongs to the imide ring containing heterocyclic class of compounds which possess extensive biological activities [2]. They have engrossed attention in medicinal chemistry due to their wide range of medicinal applications such as anticonvulsant [3], anti-inflammatory [4], analgesic, hypoglycemic [5], antimicrobial $[6,7]$, androgen receptor antagonists [8], antitumor [9], anxiolytic [10], anti-HIV-1 [11], anthelmintic [12], and immunomodulatory activities. Phthalimides have also been used as inhibitors of tumor necrosis factor alpha (TNF-alpha) that plays an important role in different physiological immune systems [13]. Phthalimides have served as starting materials and intermediates for the synthesis of many types of therapeutic synthons, alkaloids, and pharmacophores and also been used as herbicides to control bacterial contamination $[14,15]$.

Due to wide range of applications in medicinal chemistry, interest is increasing in the synthesis and biological activities of phthalimides and its derivatives. So, we planned to synthesize the $N$-aryl phthalimides from phthalic acid and aryl amines and evaluate them biologically to find out the novel lead candidates. Herein, we report the synthesis of $\mathrm{N}$-aryl phthalimides 1-7 and their biological screening for antioxidant and anti-inflammatory potentials. All the synthesized compounds have significant antioxidant active, whereas compounds $\mathbf{1}$ and $\mathbf{4}$ showed potent antioxidant potential, much better potential as compare to the standard BHA.

\section{Materials and Methods}

2.1. Experimental. All the reagents and chemicals were of analytical grade purchased from Sigma-Aldrich and used as such. Melting points were measured on a Gallen Kamp 
apparatus (Loughborough, England) and are uncorrected. The ${ }^{1} \mathrm{H}$ and ${ }^{13} \mathrm{C}$ NMR spectra were preceded on a Bruker AMX500 spectrometer (Bruker BioSpin, Fällanden, Switzerland) in deuterated solvent with tetramethylsilane (TMS) as an internal standard. Chemical shifts are shown in ppm $(\delta)$, and coupling constants $(J)$ are presented in Hertz. ESI mass experiment was done on Agilent Triple Quadrupole 6410 QQQ LC-mass spectrometer with ESI \pm ion source (gas temperature $350^{\circ} \mathrm{C}$, nebulizer pressure $60 \mathrm{psi}$, and flow rate of gas $10 \mathrm{~L} / \mathrm{min}$ ) operating in the \pm both scan ionization modes with direct infusion method in the presence of solvent methanol/water $(1: 1 \mathrm{v} / \mathrm{v})$ with flow rate $0.2 \mathrm{~mL} / \mathrm{min}$. Thin layer chromatography (TLC) was performed on precoated TLC plates (silica gel $\mathrm{F}_{254}$, Merck, Germany); the UV detection was done at low wavelength $254 \mathrm{~nm}$ and sprayed with ceric sulfate in $10 \% \mathrm{H}_{2} \mathrm{SO}_{4}$ (heating at $120^{\circ} \mathrm{C}$ ).

2.2. General Procedure for the Synthesis of Phthalimides through L-Proline-Catalyzed Reaction. The phthalic acid $(1.0 \mathrm{mmol})$, aryl amine $(1.0 \mathrm{mmol})$, and L-proline $(0.5 \mathrm{mmol})$ were sequentially added in ethanol $(5.0 \mathrm{~mL})$ into a rb (round bottom) flask to form a solution. The resultant mixture was stirred at $30^{\circ} \mathrm{C}$ room temperature for six hours. After completion of the reaction, the reaction mixture was then diluted with EtOAc ethyl acetate and washed with water. The organic phase was dried, filtered, and concentrated to give the pure phthalimide product. Purity of the products was checked by TLC.

2.2.1. N-(4-Methoxyphenyl)isoindoline-1,3-dione 1. Yield: 94\%; m.p. $107^{\circ} \mathrm{C}$; ${ }^{1} \mathrm{H}$ NMR $\left(500 \mathrm{MHz}, \mathrm{CDCl}_{3}\right) \delta_{\mathrm{H}} 7.04(\mathrm{~d}, 1 \mathrm{H}$, $J=8.5 \mathrm{~Hz}), 7.35(\mathrm{~d}, 2 \mathrm{H}, J=8.5 \mathrm{~Hz}), 7.80(\mathrm{~m}, 2 \mathrm{H}), 7.96(\mathrm{~m}, 2 \mathrm{H})$, $3.88\left(\mathrm{~s}, 3 \mathrm{H}, \mathrm{OCH}_{3}\right) ;{ }^{13} \mathrm{C} \mathrm{NMR}\left(125 \mathrm{MHz}, \mathrm{CDCl}_{3}\right) \delta_{\mathrm{C}}$ $167.5 \times 2,159.2,134.3 \times 2,131.8 \times 2,127.9 \times 2,124.2,123.6 \times 2$, $114.5 \times 2$, 55.5. ESIMS $m / z \mathrm{C}_{15} \mathrm{H}_{11} \mathrm{NO}_{3} 254$.

2.2.2. $N$-(Phenyl)isoindoline-1,3-dione 2. Yield: 93\%; m.p. $101^{\circ} \mathrm{C} ;{ }^{1} \mathrm{H}$ NMR $\left(500 \mathrm{MHz}, \mathrm{CDCl}_{3}\right) \delta_{\mathrm{H}} 7.43(\mathrm{~m}, 3 \mathrm{H}), 7.52(\mathrm{~d}$, $2 \mathrm{H}, J=8.0 \mathrm{~Hz}), 7.83(\mathrm{dd}, 2 \mathrm{H}, J=3.0 \& 8.5 \mathrm{~Hz}), 7.99(\mathrm{dd}, 2 \mathrm{H}$, $J=3.0 \& 8.5 \mathrm{~Hz}) ;{ }^{13} \mathrm{C} \mathrm{NMR}\left(125 \mathrm{MHz}, \mathrm{CDCl}_{3}\right) \delta_{\mathrm{C}} 167.3 \times 2$, $134.4 \times 2, \quad 131.7 \times 2,129.1 \times 2,128.1,126.6 \times 2,123.7 \times 3$. ESIMS $m / z \mathrm{C}_{14} \mathrm{H}_{9} \mathrm{NO}_{2} 224$.

2.2.3. N-(4-Chlorophenyl)isoindoline-1,3-dione 3. Yield: 92\%; m.p. $105^{\circ} \mathrm{C} ;{ }^{1} \mathrm{H}$ NMR $\left(500 \mathrm{MHz}, \mathrm{CDCl}_{3}\right) \delta_{\mathrm{H}} 7.43(\mathrm{~d}, 2 \mathrm{H}$, $J=8.5 \mathrm{~Hz}), 7.51(\mathrm{~d}, 2 \mathrm{H}, J=8.5 \mathrm{~Hz} \mathrm{H}), 7.82(\mathrm{dd}, 2 \mathrm{H}, J=3.0 \&$ $8.0 \mathrm{~Hz}), 7.98(\mathrm{dd}, 2 \mathrm{H}, J=3.0 \& 8.0 \mathrm{~Hz}) ;{ }^{13} \mathrm{C}$ NMR $(125 \mathrm{MHz}$, $\left.\mathrm{CDCl}_{3}\right) \quad \delta_{\mathrm{C}} 167.0 \times 2,134.5 \times 2,133.8,131.6 \times 2,130.2$, $129.3 \times 2,127.6 \times 2,123.8 \times 2$. ESIMS $m / z \mathrm{C}_{14} \mathrm{H}_{8} \mathrm{ClNO}_{4} 258$.

2.2.4. N-(4-nitro)isoindoline-1,3-dione 4. Yield: 95\%; m.p. $108.0^{\circ} \mathrm{C}$; ${ }^{1} \mathrm{H}$ NMR $\left(500 \mathrm{MHz}, \mathrm{CD}_{3} \mathrm{OD}+\mathrm{CDCl}_{3}\right) \delta_{\mathrm{H}} 7.42(\mathrm{~m}$, $2 \mathrm{H}), 7.56(\mathrm{~d}, 2 \mathrm{H}, m), 7.80(\mathrm{dd}, 2 \mathrm{H}, m), 7.91(\mathrm{dd}, 2 \mathrm{H}, m) ;{ }^{13} \mathrm{C}$ $\mathrm{NMR}\left(125 \mathrm{MHz}, \mathrm{CD}_{3} \mathrm{OD}+\mathrm{CDCl}_{3}\right) \delta_{\mathrm{C}} 167.3 \times 2,134.4 \times 2$, $131.7 \times 2,129.1 \times 2,128.1 \times 2,126.6 \times 2,123.7 \times 2$. ESIMS $\mathrm{m} / z$ $\mathrm{C}_{14} \mathrm{H}_{8} \mathrm{~N}_{2} \mathrm{O}_{4} 268$.
2.2.5. (p-Tolyl)isoindoline-1,3-dione 5. Yield: 93\%; m.p. $102^{\circ} \mathrm{C} ;{ }^{1} \mathrm{H}$ NMR $\left(500 \mathrm{MHz}, \mathrm{CDCl}_{3}\right) \delta_{\mathrm{H}} 7.34(\mathrm{~s}, 4 \mathrm{H}), 7.80(\mathrm{dd}$, $2 \mathrm{H}, J=3.0 \& 8.5 \mathrm{~Hz}), 7.96(\mathrm{dd}, 2 \mathrm{H}, J=3.0 \& 8.5 \mathrm{~Hz}), 2.43(\mathrm{~s}$, $3 \mathrm{H}) ;{ }^{13} \mathrm{C} \mathrm{NMR}\left(125 \mathrm{MHz}, \mathrm{CDCl}_{3}\right) \delta_{\mathrm{C}} 167.4 \times 2,138.2,134.3 \times 2$, $131.8 \times 2,129.8 \times 2,129.0,126.4 \times 2,123.7 \times 2,21.2$. + ESIMS $m / z \mathrm{C}_{15} \mathrm{H}_{11} \mathrm{NO}_{2} 238$.

2.2.6. (o-Tolyl)isoindoline-1,3-dione 6. Yield: 95\%; m.p. $103^{\circ} \mathrm{C} ;{ }^{1} \mathrm{H}$ NMR $\left(500 \mathrm{MHz}, \mathrm{CDCl}_{3}\right) \delta_{\mathrm{H}} 7.23(\mathrm{~d}, 1 \mathrm{H}$, $J=7.5 \mathrm{~Hz}), 7.35(\mathrm{~m}, 1 \mathrm{H}), 7.40(\mathrm{~s}, 2 \mathrm{H}), 7.81(\mathrm{dd}, 2 \mathrm{H}, J=3.0$ \& $8.5 \mathrm{~Hz}), 7.99(\mathrm{dd}, 2 \mathrm{H}, J=3.0 \& 8.5 \mathrm{~Hz}), 2.24(\mathrm{~s}, 3 \mathrm{H})$; ${ }^{13} \mathrm{C} \mathrm{NMR}\left(125 \mathrm{MHz}, \mathrm{CDCl}_{3}\right) \delta_{\mathrm{C}} 167.3 \times 2,136.5,134.3 \times 2$, $132.0, \quad 131.1, \quad 130.6 \times 2, \quad 129.4, \quad 128.7, \quad 126.9123 .7 \times 2$, 18.0. +ESIMS $m / z \mathrm{C}_{15} \mathrm{H}_{11} \mathrm{NO}_{2} 238.253$, found 1088.578 .

2.2.7. N-(2-Chloro-4-methoxyphenyl)isoindoline-1,3-dione 7. Yield: $94 \%$; m.p. $110^{\circ} \mathrm{C}$; ${ }^{1} \mathrm{H}$ NMR $\left(500 \mathrm{MHz}, \mathrm{CD}_{3} \mathrm{OD}+\right.$ $\left.\mathrm{CDCl}_{3}\right) \delta_{\mathrm{H}} 7.44$ (brs, 1H), 7.42 (brs, $\left.1 \mathrm{H}\right), 7.06$ (brs, $1 \mathrm{H}$ ), 7.80 (brs, 2H), 7.91 (brs, 2H), $3.91\left(\mathrm{~s}, 3 \mathrm{H}, \mathrm{OCH}_{3}\right) ;{ }^{13} \mathrm{C} \mathrm{NMR}$ $\left(125 \mathrm{MHz}, \quad \mathrm{CD}_{3} \mathrm{OD}+\mathrm{CDCl}_{3}\right) \quad \delta_{\mathrm{C}} 171.5 \times 2,158.8, \quad 138.7$, $132.4 \times 2,130.2,128.3,126.5,115.9 \times 2,135.4 \times 2,127.7 \times 2$, 60.0. +ESIMS $m / z \mathrm{C}_{15} \mathrm{H}_{10} \mathrm{ClNO}_{3} 288$.

\subsection{Biological Assays}

2.3.1. Inhibition of Albumin Denaturation Assay. Anti-inflammatory potential as membrane stabilization of the products 1-7 was evaluated by modified method [16]. The reaction mixture consists of test solution $(1 \mathrm{mg} / \mathrm{ml})$ and $1 \%$ aq. solution of bovine albumin fraction. The $\mathrm{pH}$ of the reaction mixture was adjusted by using small amount of $\mathrm{HCl}$. The reaction mixture was incubated for $20 \mathrm{~min}$ at $37^{\circ} \mathrm{C}$ and then heated for $20 \mathrm{~min}$ at $51^{\circ} \mathrm{C}$. After cooling of the tubes, the turbidity was measured at $660 \mathrm{~nm}$. Aspirin was used as a standard. The experiment was repeated thrice, and the percent inhibition of protein denaturation was calculated as follows:

$$
\% \text { inhibition }=\left[\frac{\left\{\text { Abs control }-\mathrm{Abs}_{\text {test }}\right\}}{\text { Abs control }}\right] \times 100 \text {, }
$$

where Abs control is absorbance without any sample and $\mathrm{Abs}_{\text {test }}$ is the absorbance of test.

2.3.2. Membrane Stabilization Assay (Heat-Induced Hemolysis). Anti-inflammatory potential as membrane stabilization of the products 1-7 was evaluated by reported method [17]. Red blood cells suspension was prepared as follows: freshly collected human whole blood $(10 \mathrm{ml})$ was transferred to the anticoagulant-containing centrifuge tubes. The tubes were centrifuged for $10 \mathrm{~min}$ at $3000 \mathrm{rpm}$ and then washed thrice with normal saline. The blood volume was measured and reconstituted as $10 \% \mathrm{v} / \mathrm{v}$ suspension of normal saline. The reaction mixture $(2 \mathrm{ml})$ was prepared with $1 \mathrm{ml}$ of test sample $(1 \mathrm{mg} / \mathrm{ml})$ solution and $1 \mathrm{ml}$ of $10 \%$ red blood cells suspension. Aspirin was used as a standard drug. In the control test tube, saline was added instead of test sample. The reaction mixtures were incubated for $30 \mathrm{~min}$ at $56^{\circ} \mathrm{C}$ on 
water bath, and then tubes were kept under running tap water for cooling. The reaction mixture was centrifuged for $5 \mathrm{~min}$ at $2500 \mathrm{rpm}$, and the absorbance of released hemoglobin in the supernatant was measured at wavelength $560 \mathrm{~nm}$. The experiment was repeated thrice. The estimation of percentage membrane stability was performed by using this expression:

Percent heat-induced hemolysis $=$

$$
\frac{\text { OD of control - OD of test }}{\text { OD of control }} \times 100 \text {. }
$$

The membrane stabilization percentage or protection was calculated by using this formula:

$$
\begin{aligned}
& \text { Percentage protection }= \\
& 100-\frac{\text { OD of control }- \text { OD of test }}{\text { OD of control }} \times 100 .
\end{aligned}
$$

\subsection{In Vitro Antioxidant Activities}

2.4.1. Hydrogen Peroxide Scavenging Assay. Antioxidant potential of the products 1-7 was measured through the reported spectrophotometric method [18]. $2 \mathrm{~mL}$ of hydrogen peroxide $\mathrm{H}_{2} \mathrm{O}_{2}(20 \mathrm{mM})$ in phosphate buffer saline was added to $1 \mathrm{~mL}$ of test compound at concentration ranging from 62.5 to $500 \mu \mathrm{M}$. The absorbance was measured at $230 \mathrm{~nm}$ after $10 \mathrm{~min}$ on ELISA plate reader (SpectraMax Plus 384 Molecular Device, USA) against a blank solution of phosphate buffer without $\mathrm{H}_{2} \mathrm{O}_{2}$ and compared with the reference compound ascorbic acid. The $\mathrm{IC}_{50}$ values were calculated by using EZ-Fit Enzyme Kinetics Program (Perrella Scientific Inc., Amherst, USA). $\%$ Scavenging of $\mathrm{H}_{2} \mathrm{O}_{2}$ was calculated by following formula:

$\%$ scavenged $\left[\mathrm{H}_{2} \mathrm{O}_{2}\right]=\left[\frac{(\text { Abs control }- \text { Abs sample })}{\text { Abs control }}\right] \times 100$.

2.4.2. DPPH Radical Scavenging Assay. Free radical scavenging activity of the products was measured by 1,1diphenyl-2-picrylhydrazyl (DPPH) through reported method [19]. In brief, $0.1 \mathrm{mM}$ solution of DPPH in EtOH was prepared. $90 \mu \mathrm{L}$ of DPPH solution was added to $10 \mu \mathrm{L}$ of test compound solution that was prepared in ethanol at concentration ranging from 62.5 to $500 \mu \mathrm{M}$. The mixture was shaken and allowed to settle down for $30 \mathrm{~min}$ at room temperature. The absorbance was measured at wavelength $517 \mathrm{~nm}$ by using ELISA plate reader (SpectraMax Plus 384 Molecular Device, USA). Butylated hydroxyanisole was used as standard and experiment was done in triplicate. The $\mathrm{IC}_{50}$ values were then calculated using the EZ-Fit Enzyme Kinetics program (Perrella Scientific Inc., Amherst, USA). The percent DPPH scavenging effect was calculated by using following equation:
DPPH scavenging effect $(\%)$ or Percent inhibition $=$

$$
\frac{A_{\mathrm{o}}-A_{1}}{A_{\mathrm{o}}} \times 100,
$$

where $A_{\mathrm{o}}$ was the absorbance of control reaction and $A_{1}$ was the Absorbance of test or standard sample.

2.4.3. Lipoxygenase Inhibition Assay. Linoleic acid, lipoxygenase (EC 1.13.11.12) type I-B Soybean, and other chemicals were purchased from Sigma (St. Louis, MO). Inhibitory activity by lipoxygenase was measured by the reported method [20]. Sodium phosphate buffer $160 \mu \mathrm{L}(100 \mathrm{mM}, \mathrm{pH}$ 8.0), $10 \mu \mathrm{L}$ of test compound solution in methanol (concentrations 5-500 $\mu \mathrm{M}$ ), and lipoxygenase solution $20 \mu \mathrm{L}$ (enzyme 130 units/well) were added in all wells, mixed, and incubated at $27^{\circ} \mathrm{C}$ for $12 \mathrm{~min}$. Then the reaction was initiated by addition of $10 \mu \mathrm{L}$ of substrate solution $(0.12 \% \mathrm{w} / \mathrm{v}$ tween- 20 , linoleic acid, $0.5 \mathrm{mM}, 1: 2$ ) in all wells, absorbance was measured at $234 \mathrm{~nm}$ after $15 \mathrm{~min}$, and \% inhibition was determined by (5). All reactions were done in triplicates. Baicalein was used as positive control [21]. $\mathrm{IC}_{50}$ values were determined by monitoring the concentrations of tested compounds on $50 \%$ inhibition. The $\mathrm{IC}_{50}$ values were calculated by using EZ-Fit Enzyme Kinetics Program (Perrella Scientific Inc., Amherst, USA).

\section{Results and Discussion}

3.1. Chemistry. A series of $N$-aryl phthalimides was prepared through the reaction of phthalic acid with aryl amines (anilines) in ethanol under mild condition with L-proline as catalyst at room temperature. Literature shows that mostly $\mathrm{N}$ substituted phthalimides were prepared by the reaction of phthalic anhydride with anilines under somewhat harsh conditions, that is, at high temperature or strong catalyst. However, in this study, $N$-aryl phthalimides were prepared under mild-conditioned simple reaction in excellent yields with L-proline catalyst, and this synthetic route is reported for the first time (Scheme 1). Before using this reaction to synthesize the products, the reaction was adjusted and optimized to obtain excellent yield of $\mathrm{N}$-aryl phthalimides by the absence and presence of various catalysts, namely, $\mathrm{AlCl}_{3}, \mathrm{CH}_{3} \mathrm{COOH}$, $\mathrm{BBr}_{3}$, L-serine, L-arginine, L-lysine, and L-proline. Overall, percentages of products were somewhat better in amino acids while excellent in L-proline without side products (Table 1), and then L-proline was used as a catalyst to synthesize the products $1-7$. The ${ }^{1} \mathrm{H}$ NMR spectra of products showed signals in the range of $\delta_{\mathrm{H}} 7.0-7.9 \mathrm{ppm}$, confirming the synthesis of phthalimide derivatives. The characteristic quaternary carbon signals of phthalimide product appeared at $\delta_{\mathrm{C}} 167 \mathrm{ppm}$ in the ${ }^{13} \mathrm{C}$ NMR spectra, while other signals were observed in the range of $\delta_{\mathrm{C}} 123-139 \mathrm{ppm}$. The methoxy group showed NMR signals at $\delta_{\mathrm{H}} 3.88, \delta_{\mathrm{C}} 55.5$ and $\delta_{\mathrm{H}} 3.91, \delta_{\mathrm{C}} 60.0$ for compounds $\mathbf{1}$ and 7, respectively. The methyl group of compounds 5 and $\mathbf{6}$ appeared at $\delta_{\mathrm{H}} 2.43, \delta_{\mathrm{C}} 21.2$ and $\delta_{\mathrm{H}} 2.24, \delta_{\mathrm{C}} 18.0$ in the NMR spectrum, respectively. All the NMR and ESI data confirmed the synthesis of phthalimide derivatives 1-7. 


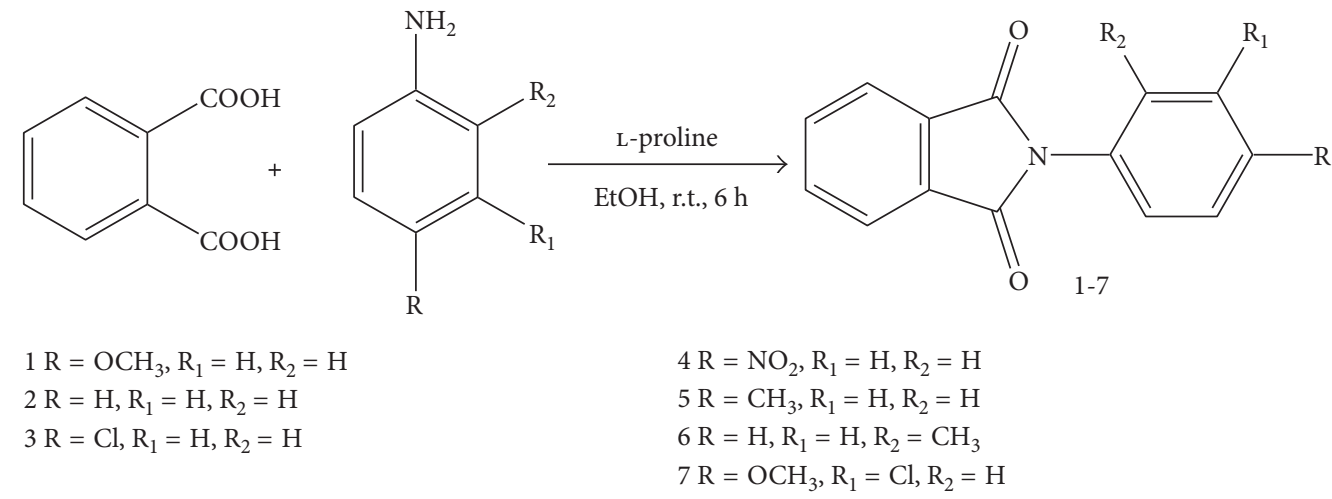

Scheme 1: Synthesis of phthalimide derivatives 1-7.

TABle 1: Product percentage under various catalysts of synthesis of phthalimide.

\begin{tabular}{lcc}
\hline Entry & Catalyst & Product $\mathbf{1}$ (\% yield) \\
\hline 1 & $\mathrm{AlCl}_{3}$ & 8 \\
2 & $\mathrm{CH}_{3} \mathrm{COOH}$ & 7 \\
3 & $\mathrm{BBr}_{3}$ & 7 \\
4 & $\mathrm{CF}_{3} \mathrm{COOH}$ & 6 \\
5 & L-serine & 10 \\
6 & L-arginine & 12 \\
7 & L-lysine & 15 \\
8 & L-proline & 94 \\
\hline
\end{tabular}

3.2. Biological Activities. Phthalimides 1-7 were biologically evaluated for their anti-inflammatory, antioxidant, and lipoxygenase enzyme inhibition activities. The antiinflammatory potential was evaluated by inhibition of albumin denaturation assay, membrane stabilization assay, and lipoxygenase enzyme inhibition assay, while antioxidant potential was evaluated through hydrogen peroxide scavenging assay and DPPH radical scavenging assay.

3.3. Antioxidant Activity. The antioxidant activity of compounds 1-7 was conducted with the DPPH well diffusion and hydrogen peroxide scavenging method. Phthalimide 2 , 3, and 5-7 showed weak DPPH radical scavenging activity, while phthalimide $\mathbf{1}$ and $\mathbf{4}$ showed strong activity with $\mathrm{IC}_{50}$ values 21.34 and $20.45 \mu \mathrm{M}$, respectively, which has much better potential as compared to the standard BHA $\left(\mathrm{IC}_{50}=44.2 \mu \mathrm{M}\right)$. However, all compounds 1-7 showed weak hydrogen peroxide scavenging activity ranging from 61.0 to $88.5 \mu \mathrm{M}$ as compared to the standard ascorbic acid $\left(\mathrm{IC}_{50}=20.77 \mu \mathrm{M}\right)$. So, it can be concluded that the phthalimides with the presence of methoxy and nitro groups at the aromatic ring are the reason of significant $\mathrm{DPPH}$ radical scavenging activity (Table 2 ).

3.4. Anti-Inflammatory Activities. In this study, the protein denaturation bioassay was performed for in vitro assessment of anti-inflammatory activity of phthalimide derivatives. Tissue protein denaturation is one of the causes of arthritic and inflammatory diseases. Autoantigen production in certain arthritic diseases may be due to in vivo denaturation of proteins. Agents which can prevent denaturation of protein therefore, would be worthwhile for antiinflammatory drug development. In our research on the anti-inflammatory activity, ability of compounds to inhibit protein denaturation was calculated. It was effective in inhibiting heat-induced albumin denaturation at concentration $1 \mathrm{mg} / \mathrm{ml}$. Maximum inhibition of $77.73 \pm 0.35 \%$ was observed for compound 2 at concentration $1 \mathrm{mg} / \mathrm{ml}$. Aspirin as standard anti-inflammatory drug showed the maximum inhibition of $95.89 \pm 0.06 \%$ at the concentration of $0.20 \mathrm{mg} / \mathrm{ml}$. Compound 2 further showed maximum membrane stabilization inhibition of $83.91 \pm 0.06 \%$ at $1 \mathrm{mg} / \mathrm{ml}$, while aspirin showed the maximum inhibition of $85.92 \pm 0.02 \%$ at $0.20 \mathrm{mg} / \mathrm{ml}$.

3.5. Lipoxygenase (LOX) Inhibition Activity. Among all the synthesized compounds, $\mathbf{1}$ and $\mathbf{4}$ showed excellent lipoxygenase enzyme inhibition activity with $\mathrm{IC}_{50}$ values of 21.34 and $20.45 \mu \mathrm{M}$, respectively, compared to the standard baicalein with $\mathrm{IC}_{50}$ value $22.6 \mu \mathrm{M}$, while rest of the compounds did not show any significant LOX inhibition activity. Phthalimide compounds containing methoxy and nitro groups in the aromatic ring showed strong LOX activity as compare to the presence of chloride and methyl groups in the ring. Thus, it can be concluded that the methoxy and nitro groups in the phthalimide compounds play a key role for the inhibition of enzyme LOX (Table 3).

\section{Conclusions}

Through the optimization of reaction, phthalimide derivatives were obtained in excellent yields through facile one-pot mild condition reaction of phthalic acid with aryl amines that was catalyzed by L-proline. All the products showed weak-to-moderate antioxidant potential, whereas compounds $\mathbf{1}$ and $\mathbf{4}$ showed outstanding and potent antioxidant and lipoxygenase enzyme inhibition potential as compared to the standard drug used. None of the phthalimide derivatives showed cytotoxic activity against all tested cancer cell lines. Among all synthesized compounds, compound 2 was found to be promising and about equal to the used standard aspirin in the inhibition of bovine serum albumin denaturation. 
TABLE 2: Anti-inflammatory and antioxidant activities of products 1-7.

\begin{tabular}{|c|c|c|c|c|}
\hline \multirow[b]{2}{*}{ Compounds } & \multicolumn{2}{|c|}{ Anti-inflammatory activity } & \multicolumn{2}{|c|}{ Antioxidant activity } \\
\hline & $\begin{array}{c}\% \text { inhibition of albumin } \\
\text { denaturation (conc. } 1 \mathrm{mg} / \mathrm{ml} \text { ) }\end{array}$ & $\begin{array}{c}\% \text { membrane stabilization } \\
\text { (conc. } 1 \mathrm{mg} / \mathrm{ml})\end{array}$ & $\begin{array}{l}\text { DPPH scavenging } \\
\mathrm{IC}_{50} \mu \mathrm{M}\end{array}$ & $\begin{array}{c}\mathrm{H}_{2} \mathrm{O}_{2} \text { scavenging activity } \\
\mathrm{IC}_{50} \mu \mathrm{M}\end{array}$ \\
\hline 1 & $74.42 \pm 0.81$ & $81.88 \pm 0.0 \mathrm{~b}$ & $27.32 \pm 0.03$ & $84.00 \pm 2.50$ \\
\hline 2 & $77.73 \pm 0.35$ & $83.91 \pm 0.06$ & $87.40 \pm 0.15$ & $61.00 \pm 2.11$ \\
\hline 3 & $49.19 \pm 1.11$ & $55.95 \pm 0.62$ & $91.70 \pm 0.05$ & $78.00 \pm 4.22$ \\
\hline 4 & $38.8 \pm 0.62$ & $54.48 \pm 0.12$ & $25.01 \pm 0.98$ & $61.00 \pm 2.23$ \\
\hline 5 & $40.16 \pm 0.31$ & $67.78 \pm 0.06$ & $69.22 \pm 0.12$ & $88.50 \pm 1.67$ \\
\hline 6 & $67.93 \pm 0.75$ & $71.29 \pm 0.06$ & $70.02 \pm 0.11$ & $79.00 \pm 1.10$ \\
\hline 7 & $56.44 \pm 0.66$ & $61.73 \pm 0.06$ & $56.11 \pm 0.11$ & $71.65 \pm 1.12$ \\
\hline Aspirin & $95.89 \pm 0.06($ conc. $0.20 \mathrm{mg} / \mathrm{ml})$ & $85.92 \pm 0.02($ conc. $0.20 \mathrm{mg} / \mathrm{ml})$ & - & - \\
\hline BHA & - & - & $44.20 \pm 0.06$ & - \\
\hline Ascorbic acid & - & - & - & $20.77 \pm 1.64$ \\
\hline
\end{tabular}

Values are expressed as mean of triplate $\pm \mathrm{SD}$.

TABLE 3: Lipoxygenase inhibition activity of compounds 1-7.

\begin{tabular}{lc}
\hline Compounds & Lipoxygenase inhibition activity: $\mathrm{IC}_{50}(\mu \mathrm{M})$ \\
\hline $\mathbf{1}$ & $21.34 \pm 0.72$ \\
$\mathbf{2}$ & $65.21 \pm 0.16$ \\
$\mathbf{3}$ & $70.51 \pm 0.65$ \\
$\mathbf{4}$ & $20.45 \pm 0.43$ \\
$\mathbf{5}$ & $55.31 \pm 0.31$ \\
$\mathbf{6}$ & $57.53 \pm 0.42$ \\
$\mathbf{7}$ & $32.22 \pm 0.16$ \\
Baicalein & 22.60 \\
\hline
\end{tabular}

\section{Data Availability}

The data used to support the findings of this study are available from the corresponding author upon request.

\section{Conflicts of Interest}

The authors declare that they have no conflicts of interest.

\section{Acknowledgments}

This research project was supported by a grant from the "Research Center of the Female Scientific and Medical Colleges," Deanship of Scientific Research, King Saud University.

\section{Supplementary Materials}

${ }^{1} \mathrm{H}-\mathrm{NMR},{ }^{13} \mathrm{C}-\mathrm{NMR}$, and ESI-MS of compounds 1-7. (Supplementary Materials)

\section{References}

[1] O. T. Jones, " $\mathrm{Ca}^{2+}$ channels and epilepsy," European Journal of Pharmacology, vol. 447, no. 2-3, pp. 211-225, 2002.

[2] L. M. Alexandre, M. L. Lidia, X. A. Joao, A. M. F. Carlos, L. G. K. Vera, and J. B. Eliezer, "Design, synthesis and antiinflammatory activity of novel phthalimide derivatives, structurally related to thalidomide," Bioorganic and Medicinal Chemistry Letters, vol. 15, no. 4, pp. 1169-1172, 2005.

[3] K. Veena and P. Pathak, "Synthesis and anticonvulsant activity of Some N-Substituted-phthalimide analogs," Pharma Innovation, vol. 1, pp. 55-59, 2012.
[4] M. L. Lidia, C. Paulo, L. M. Alexandre et al., "Synthesis and anti-inflammatory activity of phthalimide derivatives, designed as new thalidomide analogues," Bioorganic and Medicinal Chemistry, vol. 10, no. 9, pp. 3067-3073, 2002.

[5] M. Samira, E. H. Menana, and D. Khalid, "3D-QSAR for a-glucosidase inhibitory activity of $\mathrm{N}$-(phenoxyalkyl) phthalimide derivatives," International Journal of Recent Research and Applied Studies, vol. 11, pp. 395-401, 2012.

[6] E. K. Rizk, A. H. Ameen, and S. Mohamed, "Synthesis and anti-microbial activity of some substituted amino-4,6dimethyl-2-oxo-pyridine-3-carbonitrile derivatives," European Journal of Medicinal Chemistry, vol. 46, no. 10, pp. 5057-5064, 2011.

[7] L. S. Jean, R. Y. Paulo, M. C. Chung, H. T. Celio, R. P. Fernando, and Q. F. L. Clarice, "Synthesis and in vitro anti Mycobacterium tuberculosis activity of a series of phthalimide derivatives," Bioorganic and Medicinal Chemistry, vol. 17, pp. 3795-3799, 2009.

[8] S. Sharma, A. D. K. Jain, and A. Aggarwal, "A review: synthesis and biological activity of imides," Global Journal of Pharmaceutical Research, vol. 1, pp. 411-421, 2012.

[9] N. Tomomi, M. Hiroyuki, K. Ryohei, N. Mikihiko, and H. Yuichi, "Cell differentiation inducers derived from thalidomide," Bioorganic and Medicinal Chemistry Letters, vol. 15, no. 13, pp. 3212-3215, 2005.

[10] S. M. Yosuva and A. Sabastiyan, "Synthesis, characterization and antimicrobial activity of 2-(dimethylaminomethyl) isoindoline-1, 3-dione and its cobalt (II) and nickel (II) complexes," International Journal of ChemTech Research, vol. 4, pp. 805-815, 2012.

[11] U. Sharma, P. Kumar, N. Kumar, and B. Singh, "Recent advances in the chemistry of phthalimide analogues and their therapeutic potential," Mini Review in Medicinal Chemistry, vol. 10, no. 8, pp. 678-704, 2010.

[12] R. Srinivasan, K. R. Kumar, and P. Kumar, "Synthesis and antimicrobial activity of some new a N-phthilimido amino acids analogues," International Journal of Chem Tech Research, vol. 2, pp. 895-898, 2010.

[13] L. O. Okunrobo, C. O. Usifoh, and G. K. E. Scriba, "Synthesis and pharmacological evaluation of 2-hydroxy methyl benzamides as antiinflammatory and analgesic agents," Acta Poloniae Pharmaceutica, vol. 63, pp. 25-31, 2006.

[14] M. Evyapan, R. Çapan, H. Namli, O. Turhan, and G. A. Stanciu, "Formation of Langmuir-Blodgett thin film of a novel $N$-dodecylphthalimide," Material Letters, vol. 60, no. 19, pp. 2371-2374, 2006. 
[15] G. E. Winter, D. L. Buckley, J. Paulk et al., "Drug development. phthalimide conjugation as a strategy for in vivo target protein degradation," Science, vol. 348, no. 6241, pp. 13761381, 2015.

[16] L. Saso, G. Valentini, M. L. Casini et al., "Inhibition of heatinduced denaturation of albumin by nonsteroidal antiinflammatory drugs (NSAIDs): pharmacological implications," Archives of Pharmacal Research, vol. 24, no. 2, pp. 150-158, 2001.

[17] Z. K. Labu, F. R. Laboni, M. Tarafdar, M. S. I. Howlader, and M. H. Rashid, "Membrane stabilization as a mechanism of anti-inflammatory and thrombolytic activities of ethanolic extract of ariel parts of Spondiasis pinanata (Family: Anacardiaceae)," Pharmacologyonline, vol. 2, pp. 44-51, 2015.

[18] B. Deepa, G. Prema, K. B. Sai, and K. M. Cherian, "Antioxidant and free radical scavenging activity of triphala determined by using different in vitro models," Journal of Medicinal Plants Research, vol. 7, pp. 2898-2905, 2013.

[19] K. Zahid, T. M. Zahida, A. K. T. Muhammad, M. K. Khalid, I. Lubna, and L. Mehreen, "Synthesis, characterization, invitro antimicrobial and antioxidant activities of $\mathrm{Co}^{+2}, \mathrm{Ni}^{+2}$, $\mathrm{Cu}^{+2}$ and $\mathrm{Zn}^{+2}$ complexes of 3-(2-(2-hydroxy-3-methoxybenzylidene)hydrazono)indolin-2-one," Journal of Basic and Applied Sciences, vol. 11, pp. 125-130, 2015.

[20] T. H. Joung, K. Shimizu, T. Ogura, and I. Kubo, "Inhibition mode of soybean lipoxygenase-1 by quercetin," Chemistry and Biodiversity, vol. 7, no. 8, pp. 1893-903, 2010.

[21] I. Khan, M. Nisar, M. R. Shah et al., "Anti-inflammatory activities of Taxusabietane A isolated from Taxus wallichiana Zucc.," Fitoterapia, vol. 82, no. 7, pp. 1003-1007, 2011. 

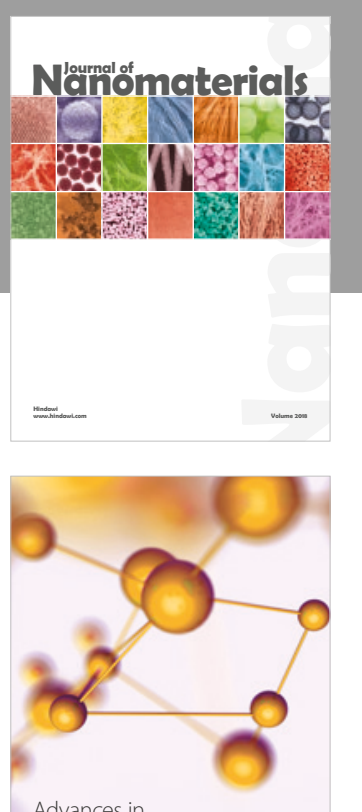

Physical Chemistry
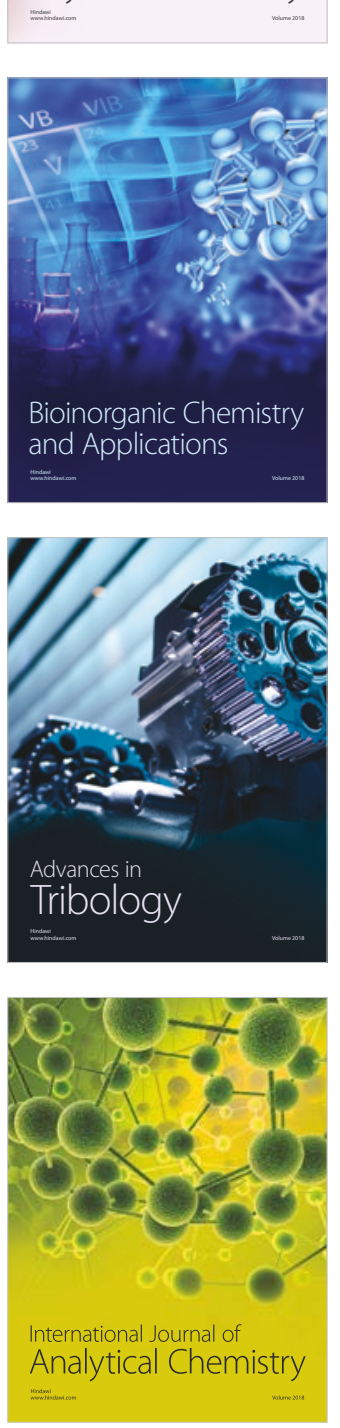

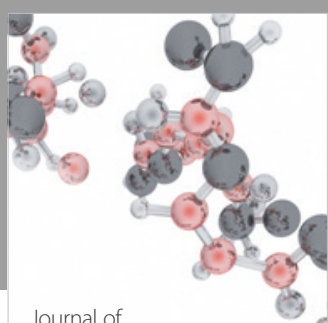

Analytical Methods

in Chemistry

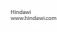

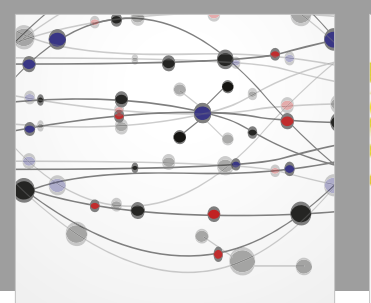

The Scientific World Journal

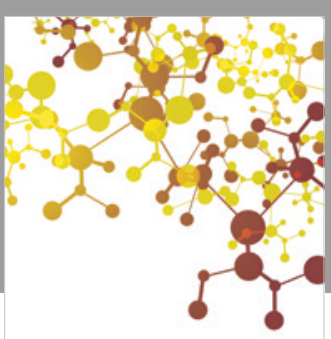

Journal of

Applied Chemistry
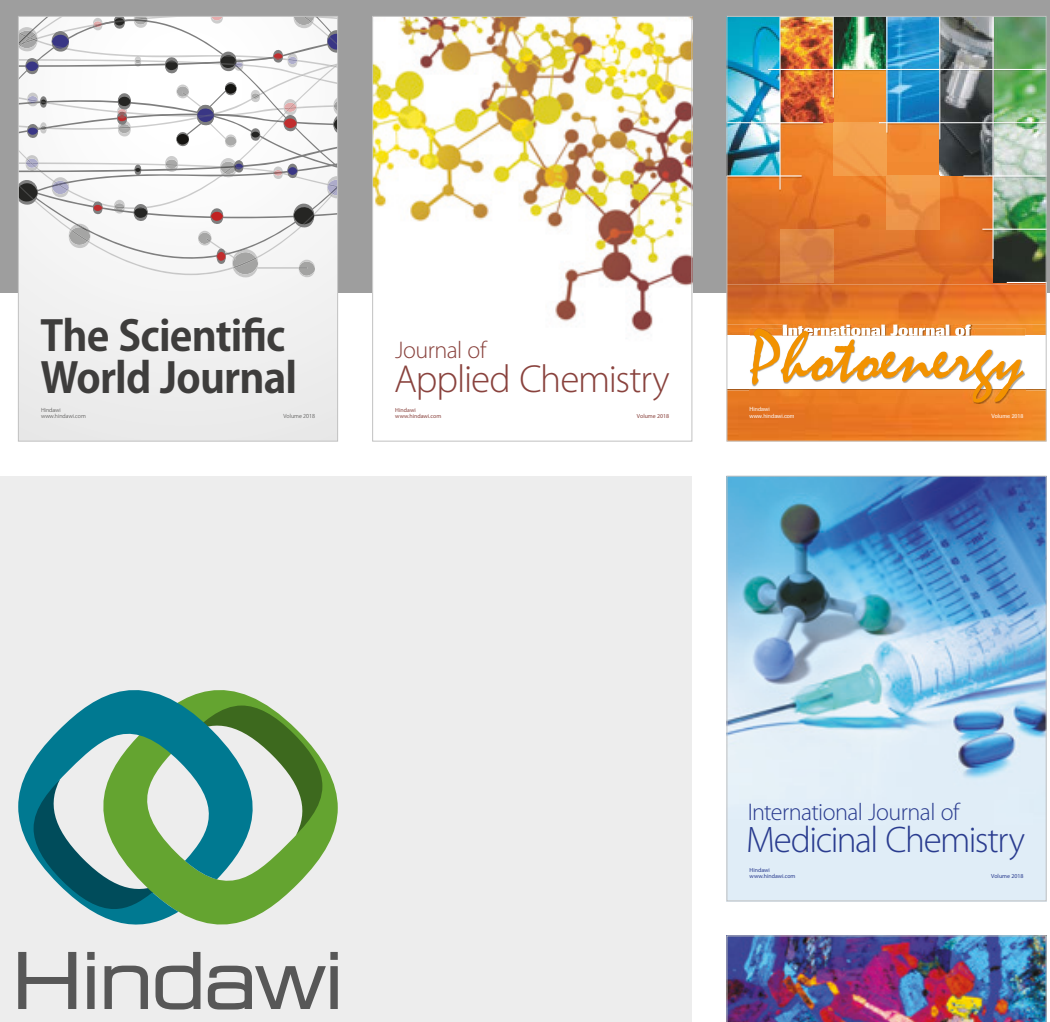

Submit your manuscripts at

www.hindawi.com
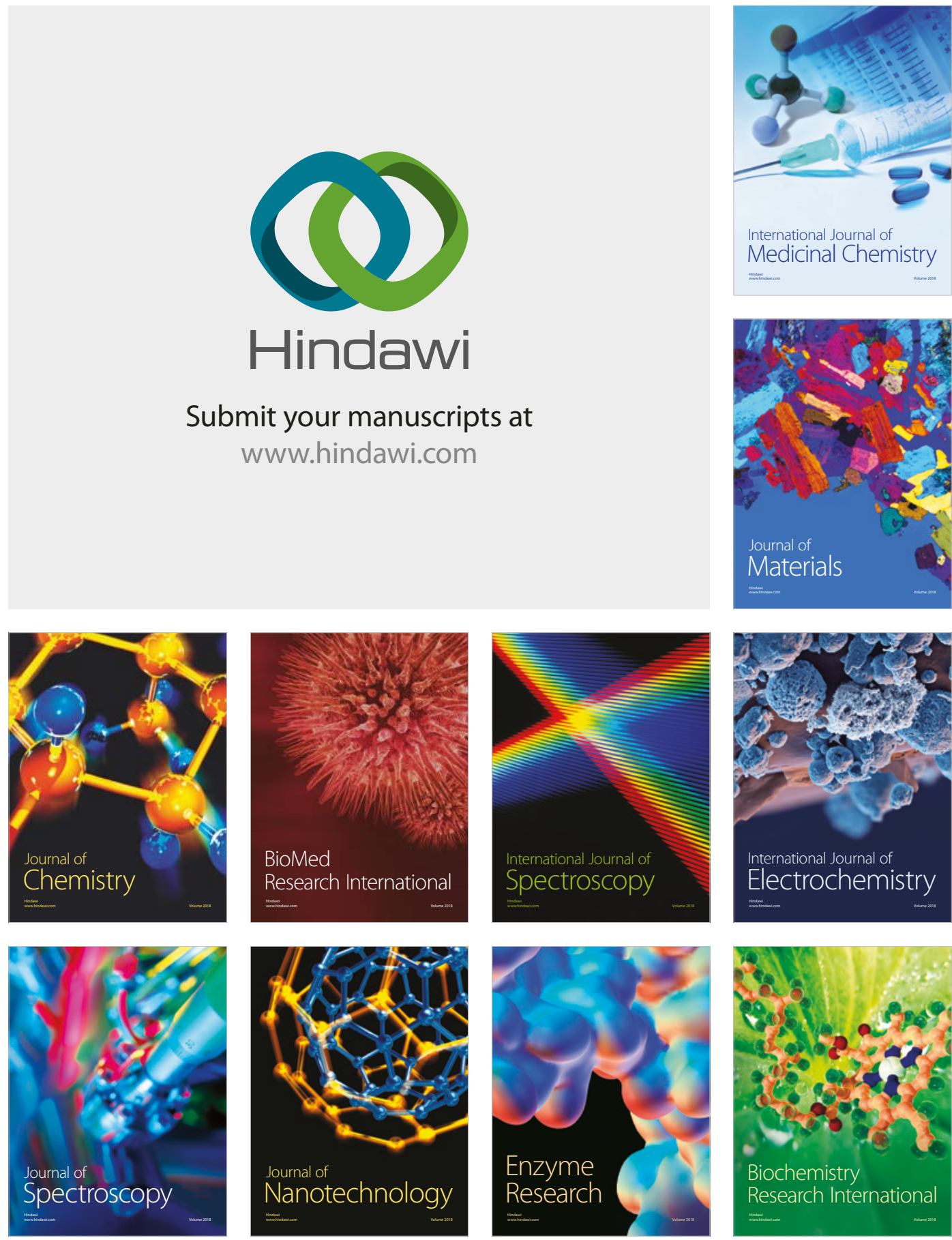
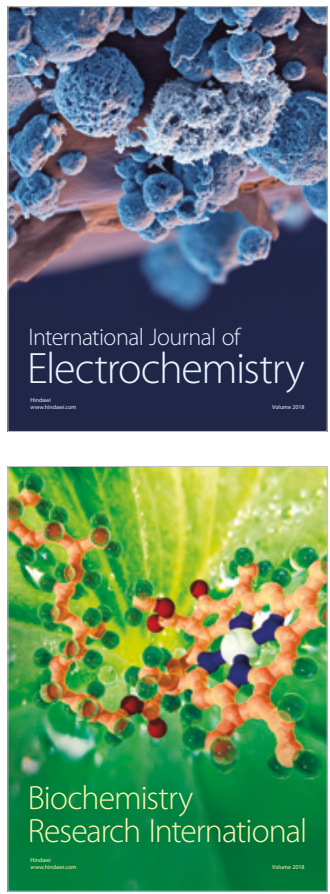